\title{
Unani formulations for management of diabetes: An overview
}

\author{
Hamiduddin ${ }^{1}$, M. A. Siddiqui ${ }^{2}$, Waris $\mathrm{Ali}^{3}$, Gazi Jahangeer ${ }^{1}$, Akhter $\mathrm{Al}^{4}$
}

${ }^{1}$ Department of Ilmul Saidla (Unani Pharmacy), National Institute of Unani Medicine Kottigepalya, Bengaluru, Karnataka, India, ${ }^{2}$ Professor, Depatment of Moalijat (Medicine), Ex-Director National Institute of Unani Medicine, Bengaluru, Karnataka, India, ${ }^{3}$ Depatment of Ilmul Saidla, Eram Unani Medical College, Lucknow, Uttar Pradesh, India, ${ }^{4}$ Depatment of Ilmul Saidla (Unani Pharmacy), ZH Unani Medical College and Hospital, Siwan, Bihar, India

\begin{abstract}
Diabetes is a leading cause of death. In India, total number of diabetic patients is expected to be 79.4 million in 2030. It is a multifactorial disease leading to several complications. Traditional medicines are being looked up once again for its treatment; the WHO also recommended its further investigation. In this review, these drug its pharmacological activity and its formulation in Greco-Arab or Unani Medicine in India is explored. Singledrug used in formulation with reported anti-diabetic and related beneficial property are Gymnema sylvestre, Azadirachta indica, Aloe vera, Momordica charantia, Acacia arabica, Eugenia jambolana, Trigonella foenum graecum, Punica granatum, etc. Phytomedicine used in Unani medicine presents an exciting opportunity for the development of new types of therapeutics for diabetes mellitus with a holistic approach, which includes various photochemical groups such as alkaloids, terpenes, and phenolics. Beside hypoglycemic activity, these drugs also have antioxidants, bitter and other activity related to disturbance in carbohydrate metabolism. They are used in the form of decoctions, infusions, tablets, pills, and powder such as Qurse Dhayabitus, Qurse Tabasheer, Safoof Gilo, Qurse Marwareed, Qurse Gulnar, Dawaul Misk Talkh, Sharbate Afsanteen, Roghane Qusht, and Ma-Usshaeer and common marketed formulation is Dolabi tablets, Qurs Kushta baiza murgh, Qurs Kushta Zamarrud, Qurs Ziabetus, Safoof Ziabtes, Diab-eaze, etc. There is the tremendous scope of Unani single and compound formulations in the comprehensive management of diabetes particularly Type- 2 diabetes; it can also be utilized as an adjuvant with the conventional drug due to its diverse and related beneficial pharmacological activity in diabetes.
\end{abstract}

Key words: Comprehensive, diabetes, formulations, management, Unani medicine

\section{INTRODUCTION}

$\mathrm{D}$ iabetes is one of the five leading causes of death. ${ }^{[1]}$ Diabetes mellitus (DM) is a metabolic disorder complex in nature, resulting in either insulin insufficiency or insulin dysfunction. It is of two types, that is, Type I diabetes (insulin dependent) and Type II diabetes (noninsulin dependent), constituting $90 \%$ of the diabetic population. ${ }^{[2]}$ The prevalence of diabetes for all age-groups worldwide was estimated to be $2.8 \%$ in 2000 and expected to be $4.4 \%$ in 2030 . In India, the total number of diabetic patients was 31.7 million in 2000 and is expected to be 79.4 million in 2030. The urban diabetic population in developing countries is projected to double from 2000 to 2030 . In another study, Akhter et al. showed that $8 \%$ Indian population is diabetic. ${ }^{[3,4]}$ Globally, 422 million adults were estimated as diabetic in
2014 and have nearly doubled since 1980, rising from $4.7 \%$ to $8.5 \%$ in the adult population. Diabetes caused 1.5 million deaths in 2012. Percentage of deaths before the age 70 is higher in low-income and middle-income countries than in high-income countries. ${ }^{[5]}$

Diabetes has become more common in the past few decades due to the stress of growing population, ecological disturbances, and rapid changing lifestyles. ${ }^{[6]}$ Type $2 \mathrm{DM}$ (T2DM) has now

Address for correspondence: Dr. Hamiduddin, Assistant Professor, Department of Ilmul Saidla (Unani Pharmacy), National Institute of Unani Medicine Kottigepalya, Magadi Main Road, Bengaluru, Karnataka, India. Phone: +91-8088739927/91-9035109537/

080-23584260. E-mail: drhamid2003@rediffmail.com

Received: $15-08-2018$

Revised: 27-09-2018

Accepted: 22-10-2018 
become an epidemic. Obesity and unsatisfactory di et al.o contribute in this. Its associated complications also contribute in medical and socioeconomic burden and impose enormous strains on the health-care system. Management includes not only diet and exercise but also anti-hyperglycemic drugs. ${ }^{[7]}$ In this work treatment of diabetes (particularly Type-2 diabetes) with traditional / Greco-Arab or Unani drugs with Unani / traditional single drug, its reported pharmacological activity and its formulations in Unani Medicine are explored with the help of reputed journal, classical as well as contemporary text.

Pathophysiology of diabetes is not fully understood, but experimental evidence suggests the involvement of free radicals in the pathogenesis of diabetes and multiple abnormalities of lipoprotein metabolism in the development of diabetic complications. ${ }^{[2,8]}$ It is currently suspected that hormones produced in fat around abdominal organs are a precipitating cause of insulin resistance which can contribute to a diagnosis of Type 2 diabetes. ${ }^{[9]}$ Diabetes is a multifactorial disease leading to several complications.

Unani medicine literature described diabetes symptomatically as characterized by excessive thirst with increased frequency of urination. It was described by various Greek physicians, and word diabetes is derived from Greek word "Diabanein" which means to "passing through" or "run through" as stated by Ibn Sina in his treatise "Al qanoon fit tib." The causes of diabetes mentioned are disordered temperament of the weakness of kidney, bladder, and liver, termed as Sue Mizaj wa Zaufe Kulliya, masana wa Jigar. ${ }^{[10]}$

\section{TRADITIONAL / UNANI (GRECO-ARAB) MEDICINE FOR DIABETES}

Behind conventional anti-diabetic drugs, antioxidants and multiple therapeutic approach for disturbance in carbohydrate metabolism are under consideration nowadays for treatment of diabetes. Traditional medicine is being looked up once again for the treatment of diabetes, near about 400 traditional plants drug treatments for diabetes have been reported, and on few drug efficacy evaluations for their hypoglycemic activity have been done on animal and human model in Type 2 diabetes. The World Health Organization recommended that traditional medicinal herbs be further investigated. ${ }^{[2]}$ Diabetes leads to various complications such as blindness, kidney failure, coronary artery disease, and gangrene of lower extremities. ${ }^{[11,12]}$ Due to to these complications, the researchers of a different system of medicine are concentrating on the development of the new anti-diabetic drugs. Antidiabetic drugs of contemporary medicine have potent and effective hypoglycemic action, but the long-term use of these drugs results in the development of various adverse effects. Therefore, there is a dire need to develop safe and effective drug for the management of Ziabetus Shakri (DM).

\section{PLANTS WITH ANTI-DIABETIC AND RELATED BENEFICIAL EFFECTS IN INDIAN SYSTEM OF MEDICINE (ISM)}

Plants with reported antidiabetic and related beneficial property after animal and clinical research are: Gymnema sylvestre, Azadirachta indica, Aloe vera, Momordica charantia, Acacia arabica, Aegle marmelos, Allium cepa, Allium sativum, Althaea officinalis, Caesalpinia bonducella, Cinnamomum zeylanicum, Emblica officinalis, E. jambolana, Ficus racemosa, Plantago ovate, Trigonella foenum graecum, Tinospora cordifolia, Punica granatum, etc. Still, further clinical research is required for the development of the antidiabetic traditional drug. Phytomedicine used in traditional medicine presents an exciting opportunity for the development of new types of therapeutics for DM, which includes various photochemical groups such as alkaloids, terpenes, and phenolics. ${ }^{[1,2]}$ Several active compounds have been isolated from the plant and herb species of ISM. They are dietary fibers, alkaloids, flavonoids, saponins, amino acids, steroids, peptides, and others. These constituents have produced potent anti-hyperglycemic, hypoglycemic, and glucose suppressive activities. They act by either insulin release from pancreatic $\beta$-cells, inhibited glucose absorption in the gut, stimulate glycogenesis in liver or increased glucose utilization by the body. These constituents also exhibited antioxidant, hypolipidemic, and anticataract activities; they restore enzymatic functions, cause repair and regeneration of pancreatic islets and the alleviation of liver and renal damage. Some active constituents obtained from plants possess insulin-like activity and can be an alternate for insulin therapy. ${ }^{[13]}$

\section{UNANI DRUGS / FORMULATIONS USED IN DHAYABITUS (DIABETES)}

Unani system of medicine can be a very rich source as a phytomedicine, many single drugs, and compound formulations are used in Unani medicine for the treatment of Dhayabitus (diabetes). Phytomedicine used in Unani medicine presents an exciting opportunity for the development of new therapeutics / formulations for DM, which include various photochemical groups such as alkaloids, terpenes, and phenolics. Besides hypoglycemic activity, these drugs also have antioxidants, bitter, and other activity related to a disturbance in carbohydrate metabolism. They are used in the form of decoctions, infusions, tablets, pills, powder, confection, etc.

Example of single drugs used for the treatment of Dhayabitus (diabetes) in Unani medicine is Gule surkh, Gulnaar, Roghane gul, Roghane Neelufar, Aabe Jangali Kaasni, Gile Armani, Sandal Safed, Tukhme Khurfa, Tukhme Kahu, Rubb Angoor Khaam, Aabe Khurfa Sabz, Loabe Isapghol, and Kishneez Khushk. ${ }^{[14]}$ Commonly used formulations for diabetes are 
Qurse Dhayabitus, Itrifal kishneezi, Qurse Tabasheer, Qurse Dhayabitus Kafoori, Jawarish Amla, Safoof Gilo, Safoof Banslochan, Qurse Marjaan, Qurse Marwareed, Khameera Abresham Alwi Khan, Safoof Sandal, Qurse Gulnar, Majun Masikul Baul Haar, Jawarish Zaroni, Habbe Ayarij, Dawaul Misk Talkh, Sharbate Afsanteen, Sharbat e Bazoori, Jawarish Jalinoos, Sharbate Abresham, ${ }^{[15]}$ Jawarish Zeera, Roghane Qusht, Roghan Pista, Roghane Badam, ${ }^{[16,17]}$ Ma-us-shaeer, Sharbate Anar tursh, Sharbat e Humaz, Qurse Kafoor, Qurse Tabasheer, Qurse Ziabetus, Safoof Dhayabitus, Safoof Sandal Dhayabitus wala, Safoof hindi,Shikanjbeen asli, and Qurse Dhayabitus, ${ }^{[18]}$ Qurse Tabasheer, Qurse Tabasheer Gulnari, Qurse Dhayabitus, ${ }^{[19]}$ Qurse Tabasheer mulaiyan, Qurse Tabasheer Kafoori, Qurse Tabasheer, Qurse Tabasheer Kafoori mulaiyan ${ }^{[20]}$ Qurse Tabasheer, Qurse Tabasheer qabiz, Qurse Tabasheer mulaiyan ${ }^{[21]}$ Qurse Tabasheer, ${ }^{[14]}$ Qurse Ziabetus Khas, Qurse Ziabetus Sada, ${ }^{[22]}$ Triphala formulation, ${ }^{[23]}$ and Safoof Ziabetus. ${ }^{[24]}$

Safoof Ziabetus also have many variants in several texts of Unani medicine, such as it contains Gudmar boti, Soonth, and Jamun; ${ }^{[24]}$ Gudmar booti and Jamun chal (bark); Gudmar booti, Jamun, Afyun, Bisbasa, and Ilaichi kalan; ${ }^{[25]}$ Gilo, Gudmar, and Shaker(sugar) ${ }^{[26]}$. Its variants are named as Safoof Ziabetus Sada, Sofoof Ziabetus Dulabi, and Safoof Ziabetus Qawi. ${ }^{[22]}$

Qurse tabasheer is commonly used in Unani medicine for diabetes, different category of Qurse tabasheer is mentioned in Unani text with different ingredients and indications including diabetes, these are as follows: Qurse Tabasheer, Qurse Tabasheer qabiz, Qurse Tabasheer gulnari, Qurse Tabasheer Afyuni, Qurse Tabasheer Raazi, Qurse Tabasheer kafoori, Qurse Tabasheer Kafoori mulaiyan, Qurse Tabasheer Loolooi sagheer, Qurse Tabasheer mushil, Qurse Tabasheer mulaiyan, Qurse Tabasheer mumsik, Qurse Tabasheer kafoori loolooi, and Qurse tabasheer sartani. ${ }^{[18-21,27,28]}$ Different formulae of Qurs Tabasheer: Several formulations with the different ingredient in the name of Qurse Tabasheer alone are mention in Unani text. Formulation mention in the name of Qurse Tabasheer in Al-Qarabadeen, ${ }^{[18]}$ Qarabadeene Najmul Ghani, ${ }^{[20]}$ Qarabadeene Majeedi, ${ }^{[21]}$ and Kamilus Sana contains different ingredients, ${ }^{[14]}$ whereas formulation of Qurse Tabasheer mention in Bayaaze Kabeer ${ }^{[29]}$ Kitabul Murakkabat Al Maroof Makhzan ul Murakkabat, ${ }^{[30]}$ and Kitab Al Murakkabat, ${ }^{[31]}$ contains same ingredients, that is, Tabasheer, Gule Surkh, Gulnar, Tukhme kahu, Tukhme khurfa, and Gile Armani and is indicated in the treatment of Dhayabitus (Diabetes) and its dose mention is $5 \mathrm{~g}$.

\section{COMMON MARKETED FORMULATION OF UNANI MEDICINE FOR TREATMENT OF DIABETES}

Dolabi tablets, Qurs Tabasheer, Qurs Kushta baize murgh, Qurs Kushta Zamarrud, Garlitab, Qurs Ziabitus, diabetic care tablets, Gurmar, Neem and Fenugreek capsule, Hoodiab capsule, Jawarish Zarooni Sada, Jawarish Mastagi sada, Shugar no, Safoof Ziabtes dulabi, Herbo diabecon, and Diab-eaze,$^{[32]}$ present marketed formulations are mentioned in Table 1.

Common ingredients present in commonly marketed 23 anti-diabetic formulations of Unani medicine / Pharmacy in decreasing order of their presence in the formulation are Jamun (E. jambolana) - 10, Gudmar booti (G. sylvestre) - 9, Tabasheer-6, Aqaqia / Babool (A. arabica) - 6, Methi / Hulba (T. foenum-graecum) - 5, Karela (M. charantia) - 5, Kushta baiza murgh (ash of hen's egg shells)-4, Gilo (T. cordifolia) - 4, Gulnar (P. granatum) - 4, Kalonji seeds (Nigella sativa)-3, Shilajeet-3, Tukhme kahu (Lactuca sativa)-3, post Gular ( $F$. racemosa)-3, Chiraita talkh (Swertia chirayita) - 3, Neem (A. indica) - 3, Tukhme khurfa (Portulaca oleracaea) - 2, Gule-surkh (Rosa damascene) - 2, Camphor (Kafoor) - 2, Amla (E. officinalis) - 2, Rubb-ussoos (Glycyrrhiza glabra) - 1, Zanjabeel (Zingiber officinalis) - 1, etc. Out of surveyed formulations, only three were found to be pharmacopeial formulations rest were patient and propriety formulations.

\section{VALIDATION WORK DONE ON SOME UNANI FORMULATIONS IN DIABETES}

\section{Qurse Tabasheer}

Effect of Qurs Tabasheer was assessed in streptozotocin (STZ) $60 \mathrm{mg} / \mathrm{kg}$, i.p. single shot, induced diabetic Wistar rats; level of hexokinase and glucose-6-phosphatase was decreased to a significant level while the level of fructose1-6-biphophatase was augmented. It significantly reduces the level of serum glucose, total cholesterol, triglycerides, glucose-6-phosphatase, and fructose-1-6-biphosphatase, while the magnitude of high-density lipoprotein cholesterol and hexokinase was amplified anti-hyperglycemic, antihyperlipidemic activity of Qurs Tabasheer extract was found to be more effective than standard oral hypoglycemic drug glimepiride. ${ }^{[33]}$ Daily oral administration of Qurse Tabasheer $(1 \mathrm{~g} / \mathrm{kg} /$ day $)$ for 7 days increased glucose tolerance in albino rats. After glucose loading, maximum effect was observed in $90 \mathrm{~min}$, but it was found statistically insignificant. ${ }^{[34]}$

\section{Triphala Formulation}

Terminalia chebula, Terminalia bellerica, and E. officinalis: All three components of Triphala showed significant antidiabetic properties individually and in combination (rat model of insulin resistance), it inhibited $50 \%$ of lipid peroxidation induced with $\mathrm{Fe} 2+/$, ascorbate was food to be 85.5, 27, 74, and $69 \mathrm{mug} / \mathrm{ml}$, respectively. The concentration needed for the inhibition of hydroxyl radical scavenging was $165,71,155.5$, and $151 \mathrm{mug} / \mathrm{ml}$, and that for superoxide scavenging activity 
Hamiduddin, et al.: Anti-diabetic formulations in Unani medicine

Table 1: List of present marketed Unani anti-diabetic formulations in India

\begin{tabular}{|c|c|c|c|c|c|}
\hline S. No. & Name & Dosage & Ingredients & $\mathrm{P} / \mathrm{P}$ and $\mathrm{Ph}$ & $\begin{array}{l}\text { Manufacturing industry/ } \\
\text { pharmacy }\end{array}$ \\
\hline 1. & Safoof-e-ziabetis & $3-6 \mathrm{~g}$ bid. & Gudmar booti, jamun & $\mathrm{P} / \mathrm{P}$ & $\begin{array}{l}\text { Hermas Unani Herbal Calicut, } \\
\text { India }\end{array}$ \\
\hline 2. & Cap ziabetis & 1-2 cap bid. & Darchini, pan bhadana & $\mathrm{P} / \mathrm{P}$ & $\begin{array}{l}\text { Hermas Unani Herbal } \\
\text { Pharmaceuticals, Kerala, India }\end{array}$ \\
\hline 3. & Cap ziyabaneel & 1-2 cap bid. & $\begin{array}{l}\text { Gunde-babool, bark of } \\
\text { babool, camphor }\end{array}$ & $\mathrm{P} / \mathrm{P}$ & $\begin{array}{l}\text { Hermas Unani Herbal } \\
\text { Pharmaceuticals Kerala, India }\end{array}$ \\
\hline 4. & Shakrino & 2 tablets bid. & $\begin{array}{l}\text { Aqaqia, tabasheer, } \\
\text { shilajit, Gudmar booti, } \\
\text { maghze-jamun, post } \\
\text { anar, post gular, } \\
\text { kushta khabsulhadeed, } \\
\text { kushta marjan, kushta } \\
\text { baize-e-murgh, Kushta } \\
\text { sadaf, warq nuqra }\end{array}$ & $\mathrm{P} / \mathrm{P}$ & Rex remedies Delhi \\
\hline 5. & $\begin{array}{l}\text { Kalonji sugar } \\
\text { powder }\end{array}$ & 1 tsf tid. & $\begin{array}{l}\text { Kalonji powder, } \\
\text { tukhm-e-jamun, Gudmar } \\
\text { booti, tuqme-katayla, } \\
\text { tuqm-e-kasni, tuqme-methi }\end{array}$ & $\mathrm{P} / \mathrm{P}$ & $\begin{array}{l}\text { Mohammedia Products, } \\
\text { Karimnagar, India }\end{array}$ \\
\hline 6. & Diabeat & 1-2 cap bid. & $\begin{array}{l}\text { Tukhm-e-kalonji, methi } \\
\text { seeds, tukm-e-kasni, neeb }\end{array}$ & $\mathrm{P} / \mathrm{P}$ & $\begin{array}{l}\text { Hamdard laboratories, } \\
\text { Gurugram, India }\end{array}$ \\
\hline 7. & Diabetoz & 2 cap bid. & $\begin{array}{l}\text { Asgand, banslochan, } \\
\text { chiraita, gilo, Gudmar, } \\
\text { HalelaZard, kolanji, jamun, } \\
\text { neem, methi seeds, } \\
\text { zanjibeel }\end{array}$ & $\mathrm{P} / \mathrm{P}$ & $\begin{array}{l}\text { Hakeem Baqai's Medicare }(p) \\
\text { Ltd. }\end{array}$ \\
\hline 8. & Dolabi & 1 tab bid. & $\begin{array}{l}\text { Gudmar-booti, jamun, } \\
\text { kushta-baiza-murgh, } \\
\text { tukhme-hummaz, aqaqiya, } \\
\text { labbabuz, banslochan, } \\
\text { kushtajast, kushta } \\
\text { khubsul-hadeed, gond } \\
\text { safaid }\end{array}$ & $\mathrm{P} / \mathrm{P}$ & $\begin{array}{l}\text { Hamdard laboratories, } \\
\text { Gurugram, India }\end{array}$ \\
\hline 9. & Gurmar capsules & 1 cap bid. & Gudmar booti dried extract & $\mathrm{P} / \mathrm{P}$ & Dehlvi naturals, Delhi, India \\
\hline 10. & Jamun Sirka & $10-15 \mathrm{ml} /$ day & Jamun fruit pulp, water & $\mathrm{P} / \mathrm{P}$ & Dehlvi naturals Delhi \\
\hline 11. & Kerala capsules & 2 cap. daily morning & $\begin{array}{l}\text { Karela (bitter melon) dried } \\
\text { extract, Karela powder }\end{array}$ & $\mathrm{P} / \mathrm{P}$ & Dehlvi naturals Delhi \\
\hline 12. & Karelajamunras & $10-15 \mathrm{ml} \mathrm{bid}$. & $\begin{array}{l}\text { Karela (bitter melon), } \\
\text { Jamun }\end{array}$ & $\mathrm{P} / \mathrm{P}$ & Dehlvi naturals Delhi \\
\hline 13. & Methi capsules & 2 cap bid. & $\begin{array}{l}\text { Methi dried extract, methi } \\
\text { powder }\end{array}$ & $\mathrm{P} / \mathrm{P}$ & Dehlvi naturals Delhi \\
\hline 14. & Qurs-Tabasheer & $5 \mathrm{~g}$ & $\begin{array}{l}\text { Tabasheer, tukhme-khurfa, } \\
\text { tukhme-kahu, gule-surkh, } \\
\text { gulnar, gile-armani[ }{ }^{28]}\end{array}$ & $\mathrm{Ph}$ & $\begin{array}{l}\text { Hamdard laboratories, } \\
\text { Gurugram, India }\end{array}$ \\
\hline 15. & Kerala Ras & $10 \mathrm{ml}$ bid. & Karela (bitter melon) & $\mathrm{P} / \mathrm{P}$ & Dehlvi naturals Delhi \\
\hline 16. & Qurs Ziabitis & 2 tab bid. & $\begin{array}{l}\text { Tukhme-khurfa, } \\
\text { tukhm-e-kahu, rub-us-soos, } \\
\text { tabasheer, gile-armani, } \\
\text { gul-e-surkh, kishneezkhusk, } \\
\text { aqaqia, samag-e-arabi, } \\
\text { sandal safaid, sandal surkh, } \\
\text { gulnar, camphor (NFUM) }\end{array}$ & $\mathrm{Ph}$ & $\begin{array}{l}\text { Dawakhana tibbiya college } \\
\text { AMU. Aligarh, India }\end{array}$ \\
\hline
\end{tabular}

(Contd...) 


\begin{tabular}{|c|c|c|c|c|c|}
\hline S. No. & Name & Dosage & Ingredients & $\mathrm{P} / \mathrm{P}$ and $\mathrm{Ph}$ & $\begin{array}{l}\text { Manufacturing industry/ } \\
\text { pharmacy }\end{array}$ \\
\hline 17. & $\begin{array}{l}\text { Amla Aloe vera } \\
\text { Kerala, Jamun } \\
\text { juice }\end{array}$ & $20 \mathrm{ml}$ bid. & Amla, gheekwar & $\mathrm{P} / \mathrm{P}$ & Dehlvi naturals Delhi \\
\hline 18. & $\begin{array}{l}\text { Qursekushta } \\
\text { baize murgh }\end{array}$ & $2 \mathrm{tab}$ & $\begin{array}{l}\text { Kushta baize murgh, } \\
\text { Ararot (starch) }\end{array}$ & $\mathrm{P} / \mathrm{P}$ & Dehlvi naturals Delhi \\
\hline 19. & $\begin{array}{l}\text { Qurse kushta } \\
\text { Zamrud }\end{array}$ & $1 \mathrm{tab}$ & $\begin{array}{l}\text { Kushta zamrud, } \\
\text { Ararot (starch) }\end{array}$ & $\mathrm{P} / \mathrm{P}$ & Dehlvi naturals Delhi \\
\hline 20. & Diab-Eaze & 2 cap tid. & $\begin{array}{l}\text { Gulneelofar, methi, } \\
\text { karelabeej, gilo, jamun, } \\
\text { Gudmar booti, darchini, } \\
\text { shilajit, gular }\end{array}$ & $\mathrm{P} / \mathrm{P}$ & Dehlvi naturals Delhi \\
\hline 21. & $\begin{array}{l}\text { Qurs-e-ziabetus } \\
\text { khaas }\end{array}$ & 2-3 tablets bid. & $\begin{array}{l}\text { Tabasheer, satte-gilo, } \\
\text { maghze-khasta-e-jamun, } \\
\text { Gurmar booti, } \\
\text { kushtae-baizamurgh, } \\
\text { kushtae-zamurrud, } \\
\text { loabe-aspaghol }\end{array}$ & $\mathrm{Ph}$ & $\begin{array}{l}\text { Sadar dawakhana, Delhi, } \\
\text { India }\end{array}$ \\
\hline 22. & Ziabetus-C & 6 g. powder bid. & $\begin{array}{l}\text { Important ingredient Sandal } \\
\text { safaid, Nishastae Gandum, } \\
\text { Katheera, Tukhme Kahu, } \\
\text { Gurmar booti, chiraita } \\
\text { talkh, Kushta abrak, Neem, } \\
\text { Kushta loha, kushtae hajrul } \\
\text { yahood, Amla, Gulnaar, } \\
\text { Babool, etc. }\end{array}$ & $\mathrm{P} / \mathrm{P}$ & $\begin{array}{l}\text { Qadari dawakhana Kolkata, } \\
\text { India }\end{array}$ \\
\hline 23. & Diabosky & 2 pills bid. & $\begin{array}{l}\text { Maghaz Jamun, Gudmar } \\
\text { Booti, Karela seed, } \\
\text { post Gular, Kalonji, } \\
\text { Hulba (methi), Kushta } \\
\text { Marjan, Shilajeet, Neem, } \\
\text { Sat-gilo, Chiraita talk, Gond } \\
\text { Keekar (Babool) }\end{array}$ & $\mathrm{P} / \mathrm{P}$ & $\begin{array}{l}\text { Sky herbal pharmacy Pvt. } \\
\text { Ltd., Delhi, India }\end{array}$ \\
\hline
\end{tabular}

P/P: Patent/Prioperty, Ph: Pharmacopeial . NFUM: National formulary of Unani medicine

was found to be $20.5,40.5,6.5$, and $12.5 \mathrm{mug} / \mathrm{ml}$, respectively. Extracts in $100 \mathrm{mg} / \mathrm{kg}$ body weight on oral administration significantly reduce the blood sugar level in $4 \mathrm{~h}$ in normal as well as in alloxan $(120 \mathrm{mg} / \mathrm{kg})$ induced diabetic rats. Continued, daily administration of the drug produced a sustained effect. Anti-diabetic activity of the formulation and its relationship with their antioxidant property is displayed in the work. ${ }^{[23]}$

\section{Safoof Ziabetus}

Safoof (Powder) containing Gurmar Booti (G. sylvestre) and Gilo Khushk (T. cardiofolia) was studied, showed significant response on blood sugar level in patients average reduction of $56.83 \mathrm{mg} / \mathrm{dl}(32.80 \%)$ in fasting and $67.23 \mathrm{mg} / \mathrm{dl}(26.94 \%)$ in postprandial blood sugar $(\mathrm{PPBS})$ was observed $(P<0.05) .{ }^{[35]}$

\section{Capsule Gurmar}

It is a combination of powders and aqueous dry extracts of G. sylvestre, M. charantia, T. foenum-graecum, Coccinia cordifolia, and Lagerstroemia speciosa. Study showed the presence of carbohydrates, glycosides, saponins, steroids, flavonoids, alkaloids, and tannins in the formulation. It exhibited high total antioxidant capacity $(622.326 \mathrm{mg} / \mathrm{g})$ and had high flavonoid (386.43 mg/g) and phenol (184.60 mg/g) contents. Hypoglycemia activity of the formulation was comparable to that of the standard oral hypoglycemic drug, metformin hydrochloride at the dose of $100 \mathrm{mg} / \mathrm{kg}$. Results indicate that capsule Gurmar possesses mild analgesic, antioxidant, central nervous system depressant, cytotoxic and hypoglycemic properties. ${ }^{[36]}$

\section{Dolabi}

Prokinetic activity of Unani herbomineral formulation (Dolabi) in STZ induced diabetic rats and its in vitro antioxidant activity. Percentage of gastric emptying (GE) and intestinal transit (IT) was significantly $(P<0.05)$ decreased in the diabetic rat as compared to normal control groups. In 
STZ-induced diabetic rats, Dolabi significantly $(P<0.05)$ accelerated both GE and IT as compared to diabetic control rat's exhibit in vitro antioxidant activity. ${ }^{[37]}$ Effect of a Dolabi (herbomineral formulation) on early diabetic nephropathy demonstrates that Dolabi has an ability to prevent the progression of early diabetic nephropathy. Such protective effect might be due to the presence of flavonoids (catechin, quercetin, and rutin) and triterpene saponins (oleanolic acid and gymnemic acid) present in ingredients of Dolabi which are known to possess potent antioxidant properties. ${ }^{[38]}$

Hypoglycemic potential Dolabi evaluated with pioglitazone in STZ-induced diabetic rats. Groups receiving Dolabi $(35.2 \mathrm{mg} / \mathrm{kg} /$ day $)$ and pioglitazone showed significant reductions $(P<0.05)$ in fructosamine levels and fasting plasma glucose and oral glucose tolerance test, Sluggish hypoglycemic effects were noted for Dolabi at manufacturer's recommended doses but at a higher dose; however, good glycemic control was attained, and the results were comparable to pioglitazone. ${ }^{[39]}$

\section{Damtab}

Polypharmaceutical Unani tablet contains leaf, bark, and seed of A. indica, seed of Gossypium herbaceum, leaves of G. sylvestre, petals of Rosa domascena, and seeds of Syzigium cumini as the plant constituent. The animal constituent is Kushta baiza murgh, that is, ash of eggshells of hen. Clinical study on Damtab 700 mg shows placebo-like effect whereas Damtab $1400 \mathrm{mg}$ possesses hypoglycemic effect. ${ }^{[0]}$

\section{Jawarish Zar'uni}

Prepared excluding sugar in the form of capsule exhibited a significant effect in reducing microalbuminuria, $24 \mathrm{~h}$ urinary protein and improved subjective parameters; fatigue, leg edema in diabetic nephropathy, test drug is safe, effective in the treatment of diabetic nephropathy. ${ }^{[41]}$

\section{Diabrid}

Qadri et al. ${ }^{[42]}$ evaluated antidiabetic activity of Diabrid comprising G. sylvestre, M. charaintia, E. jambolana, and T. foenum graeceium, showed dose-dependent and gradual hypoglycemic activity with no deleterious effect on kidney and liver. ${ }^{[42]}$

Qurs-e-Ziabetes obtained from Hamdard Dawakhana is a polyherbal Unani preparation for T2DM. In a clinical evaluation for its anti-diabetic effects was found to have significant therapeutic effects in T2DM with respect to lowering blood sugar levels as well as clinical improvement. ${ }^{[43]}$

Combination of Unani drugs (Several clinical trials are been conducted to evaluate combined effect of two or more drug): Combined effect of Withania coagulans Dunal and T. foenumgraecum Linn, reveals that it exhibited hypoglycemic activity and significant improvement in symptoms and signs were observed, and significant euglycemia was attained. ${ }^{[7]}$ Arusa (leaves of Adhatoda vasica Nees.) and Shoneez (seeds of $N$. sativa Linn.) studied for the hypoglycemic effect of the individual drug found to be effective $(P<0.05)$. Therefore, the study was designed to find out any synergistic effect of the combination in acute and 1 week models in healthy adult alloxan-induced diabetic albino rabbits of either sex with the standard as glibenclamide. The study revealed that the aqueous extract of test combination given orally reduced the blood glucose level. The significant reduction $(P<0.05)$ in blood glucose level started after $3 \mathrm{~h}$ and continued for $6 \mathrm{~h}$ in both the groups ${ }^{[6]}$ Anas et al. thorough review of classical and modern literature selected a formulation containing Neem, Kalaunji, Karela, Methi, and Jamun in equal quantity and conducted a clinical trial. The formulation was given in powder form, in $6 \mathrm{~g}$ BID doses for 3 months in the diagnosed patient of DM. Formulation exhibited anti-hyperglycemic activity with significant improvement in sign and symptom. ${ }^{[44]}$

Some combinations work more on symptoms of diabetes, for example, clinical study on a Unani formulation consisting of Satte Gilo (T. cardifolia), Tabasheer (Bambusa bambos), and Maghze Kanwal gatta (Nelumbo nucifera) in management of Ziabetus shakari (DM type 2) done by Khan et al. reveals that the test drug exhibited significant effect on subjective parameters such as polyuria and progressive weakness $(P<0.05)$, in polydipsia and unexplained weight loss, and tiredness $(P<0.001)$; while there was no effect in polyphagia $(P>0.05)$. On objective parameters, there was significant effect observed on urine sugar $(P<0.01)$ and glycosylated hemoglobin $(P<0.05)$, while there was no significant effect found on fasting blood sugar and PPBS $(P>0.05) \cdot .^{[45]}$

Study of diabetic peripheral neuropathy and therapeutic evaluation of Unani formulation Habbe Azaraqi in its management exhibited significant improvement in pain $(P<0.05)$, numbness $(P<0.001)$, burning sensation $(P<0.001)$, and paresthesia $(P<0.05)$ in subjective parameters in intragroup comparison. ${ }^{[46]}$ Itrifal Kishneezi showed considerable in vitro antioxidant activity in a dosedependent manner ${ }^{[47]}$ commonly used Unani drugs and drug used placed under Bitters / Musaffie Dam (Blood Purifiers) category for treatment of Dhayabitus (diabetes) in Unani formulations with reported anti-diabetic and other related activity is depicted in Tables 2 and 3.

\section{DISCUSSION}

Active principles useful in diabetes are present in Unani formulations such as dietary fibers, alkaloids, flavonoids, saponins, amino acids, steroids, peptides, and others. These drug produces potent hypoglycemic, anti-hyperglycemic, and glucose suppressive activities. Effects from the Unani formulations / compounds may be achieved by either insulin release from pancreatic $\beta$-cells, inhibited glucose absorption 
Table 2: Reported anti-diabetic and related activity in drugs used in Unani formulations

Unani name

Tukhme methi

Babool

(Aqaqia/Samaghe Arabi)

Jamun

Anar/Gulnar

Bel

Tukhme Kahu

\section{Botanical name}

Trigonella foenum graecum

Acacia arabica

Eugenia jambolana

Magze Khastae Jamun (Seed Kernels)

Antidiabetic and other favorable activities/effects

Insulin stimulating properties/hypoglycemic effect (in diabetic rats, dogs, mice, and healthy volunteers)/(in IDDM and NIDDM clinical trial), significant hypolipidemic, hypocholesterolemic, anti-oxidant activity. ${ }^{[48-52]}$

4-Hydroxyleucine (amino acid) mainly distributed in fenugreek increased glucose-stimulated insulin release by isolated islet cells in rats, mice, and humans. ${ }^{[53-56]}$

Plant extract: Secretagogue to release insulin, induces hypoglycemia (in control rats) (powdered seeds), induced-hypoglycemia (normal rabbits) initiating release of insulin from pancreatic beta cells ${ }^{[53,57]}$

Kernels antihyperglycemic, shows a reduction in blood glucose level. (pulp) Hypoglycemic activity STZ induced diabetic mice, (extracts) inhibited insulinase activity from liver and kidney. Hypoglycemic effects (Mukherjee et al., 2006), formulation Madeglucyl, prepared from the seeds of E. jambolana, showed alleviation in the symptoms of diabetes in clinical trials (Denis et al., 2008), anti-diabetic features in type 2 diabetes (glycemia rates) return to normal levels within 3-6 months in $75 \%$ of cases particularly in obese patients. Glycemia rates start to decline after 15 days; it acts by improving the ability of the body's tissues to absorb glucose, thus enhancing the effectiveness of insulin. ${ }^{[58-60]}$

Flower extracts antioxidant, anti-hyperglycemic effect with reduction in glycosylated hemoglobin levels (STZ-induced DM. in rats) ${ }^{[61]}$ Pomegranate flower has dual PPAR- $\alpha /-\gamma$ activator properties which is a major regulator of lipid and glucose metabolism and is a natural PPAR $\alpha$ and $\gamma$ agonist. ${ }^{[62]}$ Inhibition of carbohydrate digestive enzymes (a-amylase and a-glucosidase) and their phenolic content may contribute to the anti-hyperglycemic effects of pomegranate flower and peel support its claim in diabetes in Unani and Chinese Medicine ${ }^{[63]}$

Leaves reduce blood sugar and urea, serum cholesterol (alloxanized rats). With hypoglycemic activity, its extract also prevented a peak rise in blood sugar at $1 \mathrm{~h}$ in oral glucose tolerance test ${ }^{[53]}$ Hypoglycemic effect, ${ }^{[64]}$ Lactucin and lactucopicrin, isolated from Lactuca scariola have shown hypoglycemic effect (Jaffery and Harborno). ${ }^{[33]}$ Methanolic leaf extract investigated for in vitro inhibition of oxidative damage induced by UV-radiations to the Salmonella typhi bacteria and in vivo effect on the production of body enzymes, that is, catalase and superoxide dismutase. Shown significant antioxidant potential. ${ }^{[65]}$ Antioxidant activity was displayed by ethanolic extracts by means of spectrophotometric methods. ${ }^{[66,67]}$

Antioxidant potential both in vitro and in vivo, capable of protecting neurons against glucose/serum deprivation-induced cell injury (neuroprotection) have potential in neurodegenerative disorders. ${ }^{[59]}$ 
Unani name

Tukhme Khurfa

Amla

Palas

Post

Halela

Balela

Asgandh

Aam (Seed)
Terminalia belerica

Emblica officinalis

Butea monosperma

Terminalia chebula

Withania somnifera

Mangifera indica
Antidiabetic and other favorable activities/effects

Significant hypoglycemic activity effect was observed when entire plant in dried form was administered intragastrically to rabbits at dose of 1.5 and $2.0 \mathrm{~g} / \mathrm{kg}$ after 8 and $12 \mathrm{~h}$, respectively. Seeds, in a mixture with 7 other plants, administered orally to male rats at a dose of $4.0 \mathrm{~g} / \mathrm{animal}$, were active. ${ }^{[68]}$ In vitro antioxidant activity of the methanolic extract of $P$. oleracea investigated by Sanja et al. by DPPH displayed free radical scavenging activity, reducing power by $\mathrm{FeCl}$, nitric oxide free radical scavenging activity, and superoxide scavenging activity by alkaline DMSO method. Hypolipidemic activity (rich source of omega, 3 fatty acids important in preventing heart attack, and strengthening the immune system), hepatoprotective activity, neuroprotective effect and ameliorates diabetic nephropathy through suppression of renal fibrosis and inflammation (diabetic mice). ${ }^{[59,69,70]}$

Decreases lipid peroxidation, antioxidant, and hypoglycemic ${ }^{[53]}$

Antihyperglycemic ${ }^{[53]}$

Antibacterial, hypoglycemic ${ }^{[53,71]}$ aqueous extract (fruits) evaluated for its antidiabetic activity in STZ-induced mild diabetic rats and compared with tolbutamide. Oral administration of effective (dose $200 \mathrm{mg} / \mathrm{kg}$ body weight) of aqueous extract of $T$. chebula daily once for 2 months reduced the elevated blood glucose by $43.2 \%$ and significantly reduced the increase in $\mathrm{HbA1c}$. Same dose also improves elevated blood lipids as well as decreased serum insulin levels in contrast to the untreated diabetic animals. ${ }^{[72]}$ Chloroform extract of Terminalia chebula seed powder in STZ-induced diabetic rats produced dose-dependent reduction in blood glucose comparable with glibenclamide in short-term study. Significant renoprotective activity is observed in $T$. chebula treated rats. The result indicates a prolonged action in the reduction of blood glucose by $T$. chebula; this reduction is probably mediated through enhanced insulin secretion from the $\beta$-cells of Langerhans or by extra pancreatic mechanism. ${ }^{[73]}$

Antibacterial, hypoglycaemic ${ }^{[53]}$ dried $75 \%$ methanolic extract Terminalia belerica fruit in water studied in alloxan induced hyperglycemia and antioxidant defense mechanism in rats, drug prevented hyperglycemia significantly from the $6^{\text {th }}$ day of administration and $54 \%$ reduction was observed on the $12^{\text {th }}$ day. Oxidative stress was also significantly lowered by the administration of extract. ${ }^{[74]}$

Hypoglycemic, hypocholesterolemic ${ }^{[53]}$

Hypoglycemic activity (may be due to an intestinal reduction of the absorption of glucose). ${ }^{[53]}$ Alcoholic extract of Mangifera indica leaves and kernel seeds is having significant anti-diabetic effect in alloxone-induced diabetes in Wistar rats by stimulating insulin production in the pancreas. ${ }^{[75]}$ 
Table 2: (Continued)

\section{Unani name}

Pyaz

Gule Surkh

Rabbus soos

Kisneez

Zanjabeel
Rosa damascena

Glycyrrhiza glabra Linn

Coriandrum sativum Linn

Zingiber officinalis
Antidiabetic and other favorable activities/effects

Dried onion powder: Anti-hyperglycemic activity in diabetic rabbits, antioxidant and hypolipidemic activity, normalized the activities of liver (diabetic patient), onion juice significantly controlled post-prandial glucose levels. ${ }^{[53]}$

$R$. damascene methanol extract of the plant on oral administration significantly decreased blood glucose after maltose loading in normal and diabetic rats in a dose-dependent manner. In addition, it inhibited postprandial hyperglycemia comparable to acarbose. $R$. damascene was found to be a potent inhibitor of the $\alpha$-glucosidase enzyme, anti-diabetic effect may be mediated by inhibition of $\alpha$-glucosidase that suppressed carbohydrate absorption from the small intestine and can reduce the postprandial glucose level. ${ }^{[76]}$

Flavonoids-enriched fraction prepared from the EtOH extract of Glycyrrhiza glabra L. roots, exhibited PPAR-c ligand-binding activity, was also effective in preventing and/or ameliorating diabetes, abdominal obesity, and body weight gain in KK-Ay mice and/or high-fat-diet-induced obese C57BL/6J mice. ${ }^{[77]}$

Gray and Flatt (1999) have found the antidiabetic potential of coriander seeds in STZ-induced diabetic mice. (Gray and Flatt 1997) also observed an increased glucose transport and incorporation into muscle glycogen and six-fold increased insulin secretion in pancreatic b-cells potentiated by coriander seed powder in in vitro studies. ${ }^{\text {[78-80] }}$

Sanjay et al. have studied the antidiabetic effect of the juice of $Z$. officinale $(4 \mathrm{~mL} / \mathrm{kg})$, p.o. daily) for 6 weeks on STZ-induced type I diabetic rats with particular reference to the involvement of serotonin (5-hydroxytryptamine; 5-HT) receptors in glycaemic control. $Z$. officinale produced a significant decrease in fasting glucose level and increase in insulin level in diabetic rats. Treatment also caused a decrease in serum cholesterol, serum triglyceride, and blood pressure in diabetic rats. Antidiabetic activity in type I diabetic rats was possibly by involving 5-HT receptors. ${ }^{[1]}$ Ethyl acetate extract of ginger was evaluated for its antioxidant activity in terms of DPPH radical scavenging potential with an IC50 value of $4.59 \mu \mathrm{g} / \mathrm{ml}$. Antidiabetic activity was also evaluated by estimating antiglycation potential $\left(\mathrm{IC}_{50} 290.84 \mu \mathrm{g} / \mathrm{ml}\right)$. Effect of extract to enhance glucose uptake in cell lines were evaluated in L6 mouse myoblast and myotubes. Antibody-based studies in treated cells revealed the effect of EAG in expressing Glut 4 in cell surface membrane compared to control. Activity is initiated by antioxidant, antiglycation, and potential to express or transport Glut4 receptors from internal vesicles. ${ }^{\left[{ }^{[2]}\right.}$ 


\begin{tabular}{|c|c|c|}
\hline \multicolumn{3}{|c|}{ Table 2: (Continued) } \\
\hline Unani name & Botanical name & Antidiabetic and other favorable activities/effects \\
\hline Gular (Bark and fruit) & Ficus racemosa Linn & $\begin{array}{l}\text { Ethanolic extract is anti-diabetic in the experimental } \\
\text { animal. }{ }^{[83]} \text { F. racemosa bark powder and aqueous } \\
\text { extract in STZ-induced diabetic rats, displayed } \\
\text { a significant reduction in blood glucose, serum } \\
\text { cholesterol, and triglyceride levels. Aqueous } \\
\text { extract was more effective. F. racemosa bark has } \\
\text { a significant hypolipidemic and hepatoprotective } \\
\text { effect besides being a potent antihyperglycemic } \\
\text { agent. }{ }^{[84]} \text { The fruit, bark, latex, seeds, or leaves of } \\
\text { F. racemosa plant have been reported to decrease } \\
\text { blood glucose levels in diabetic animals. }{ }^{[85]}\end{array}$ \\
\hline
\end{tabular}

IDDM: Insulin-dependent diabetes mellitus, NIDDM: Non-insulin-dependent diabetes mellitus, Eugenia jambolana: E. jambolana, STZ: Streptozotocin, DM: Diabetes mellitus, PPAR: Peroxisome proliferator-activated receptor, P. oleracea: Portulaca oleracea, DPPH: 1,1-Diphenyl-2-picrylhydrazyl, DMSO: Dimethyl sulfoxid, Terminalia chebula: T. chebula, HbA1c: Glycosylated hemoglobin, Terminalia chebula: Terminalia chebula, R. damascene: Rosa damascene, Z. officinale: Zingiber officinale, F. racemosa: Ficus racemosa

Table 3: Bitters drugs with anti-diabetic and related reported actions used in Unani formulations

\begin{tabular}{ll} 
Unani name & Botanical name \\
\hline Gurmar Booti & $\begin{array}{l}\text { Gymnemma sylvester } \\
\text { (leaves) }\end{array}$
\end{tabular}

Antidiabetic and other favorable effects in traditional medicine

Hypoglycemic activity, inhibit glucose uptake in the intestine. Stimulate insulin secretion from mouse cells and isolated human islets in vitro, lowered fasting blood glucose, release insulin probably by causing regeneration of pancreatic $\beta$-cells both in vivo and in vitro. Gymnemic acids $1-4$, guarmarin shows antidiabetic activity. ${ }^{[54,86,87]}$

Kalonji Nigella sativa

Seed extracts enhance glucose-induced insulin release from rat-isolated Langerhans islets and basic sub-fraction largely contributes to this stimulatory effect. ${ }^{[88]}$ Improve the dyslipidemia associated with type 2 diabetic patients, exerts lipid-lowering and insulin-sensitizing actions in the rat, immunomodulatory activity. ${ }^{[89,90]}$ In vivo treatment with $N$. sativa seed ethanol extract exerts an insulin-sensitizing action by enhancing ACC phosphorylation (major component of the insulin-independent AMP-kinase signaling pathway) and by enhancing muscle Glut4 protien expression. ${ }^{[91]}$ Decoction (aqueous suspension) at a dose 1-2 g/kg/day displayed hypoglycemic, anti-obesity and hypolipidaemic action in Meriones shawi (desert gerbil). ${ }^{[92]}$ Seed oil significantly reduce blood suger and increase Insulin level. ${ }^{[54]}$ Effect of NSO on blood glucose concentrations was studied in STZ diabetic rats and effect of NSO, nigellone, and thymoquinone were studied on insulin secretion of isolated rat pancreatic islets in the presence of $3,5.6$ or $11.1 \mathrm{mM}$ glucose. NSO significantly reduce blood glucose concentrations after 2, 4 and 6 weeks. The blood lowering effect was not paralleled by stimulation of insulin release in the presence of NSO, nigellone or thymoquinone. indicate that the hypoglycemic effect may be mediated by extra-pancreatic actions rather than by stimulated insulin release. ${ }^{[93]}$ antioxidant activity ${ }^{[94]}$

$\begin{array}{ll}\text { Gilo } & \text { Tinospora } \\ & \text { cordifolia (Willd) Miers. } \\ & \text { Roots/stem }\end{array}$

Ailwa/Ghekwar Aloe vera and Aloe barbadensis
Hypoglycemic and hypolipidemic activity (alloxan diabetic rats) decreases the blood glucose level and increases glucose tolerance (rodents). ${ }^{[53]}$ Hexane, ethyl acetate and methanol extract of stem on oral administration were found to have potent antidiabetic activity that reduces blood sugar level in STZ-induced diabetic rats. Supplementation of methanol extract significantly decreases the glycosylated hemoglobin level as compare to diabetic control, the insulin and C-peptide levels were improved which shows the regeneration of $\beta$-cell which secretes insulin, histopathological studies of pancreas of TCS methanol extract treated groups confirm the regenerating capacity of extract. ${ }^{[95]}$

(Extracts increases glucose tolerance in both normal and diabetic rats, hypoglycemic (alloxanized diabetic rats). (Bitter principle) showed hypoglycemic effect in diabetic rats through stimulation of synthesis and/or release of insulin from pancreatic beta cells, anti inflammatory activity (improves wound healing in diabetic mice). ${ }^{[53]}$ 


\begin{tabular}{|c|c|c|}
\hline & & Table 3: (Continued) \\
\hline Unani name & Botanical name & Antidiabetic and other favorable effects in traditional medicine \\
\hline $\begin{array}{l}\text { Tukhme } \\
\text { Karela }\end{array}$ & $\begin{array}{l}\text { Momordica charantia } \\
\text { Seeds }\end{array}$ & $\begin{array}{l}\text { Potent hypoglycaemic, significant improvement in glucose tolerance in diabetic } \\
\text { subjects without any increase in serum insulin levels, increases the renewal of } \\
\text { partial cells in the pancreas or may permit the recovery of partially destroyed } \\
\text { cells and stimulates pancreatic insulin secretion. }{ }^{[59]}\end{array}$ \\
\hline Neem & Azadirachta indica & $\begin{array}{l}\text { Antihyperglycemic activity (STZ treated rats) because of increase in glucose } \\
\text { uptake and glycogen deposition in isolated rat hemidiaphragm, anti-bacterial, } \\
\text { antimalarial, antifertility, hepatoprotective and antioxidant effects. }{ }^{[53]} \text { Aqueous } \\
\text { extract of tender leaves reported to be effective in reducing blood glucose, this } \\
\text { effect was due to peripheral utilization of glucose and blocking the action of } \\
\text { epinephrine on glycogenolysis. } .^{[96]}\end{array}$ \\
\hline Chiraita & Swertia chirayita & $\begin{array}{l}\text { Stimulates insulin release from islets. }{ }^{[53]} \text { Methanolic leaf extracts contain } \\
\text { significant antibacterial and anti-diabetic potential, methanolic root has } \\
\text { potential antioxidant activity. }{ }^{[97]}\end{array}$ \\
\hline Afsanteen & Artemisia absinthium & $\begin{array}{l}\text { Ethanol extract of Artemisia absinthium in alloxan-induced diabetic rats was } \\
\text { given in a dose } 250,500 \text {, and } 1000 \mathrm{mg} / \mathrm{kg} \text { body weight in distilled water i/p, for } \\
10 \text { days. All elevated blood serum markers were reduced to significant levels } \\
\text { at both medium and high doses and also after glibenclamide treatment. }{ }^{[98]} \\
\text { Fifteen patients with diabetes mellitus in a preliminary study were treated with } \\
\text { one of the species of Artemisia (Artemisia herba-alba Asso. Extract). Results } \\
\text { displayed considerable lowering of elevated blood sugar with no adverse } \\
\text { effects. }{ }^{[99]}\end{array}$ \\
\hline
\end{tabular}

Botanical/Unani name mentioned are as correlated by NFUM ${ }^{[21]}$ and UPI. ${ }^{[100]}$ NFUM: National formulary of Unani medicine, UPI: Unani pharmacopoeia of India, $N$. sativa: Nigella sativa, NSO: Nigella sativa oil, $N$. sativa: Nigella sativa

in gut, stimulated glycogenesis in liver or increased glucose utilization by the body.

There is tremendous scope in these Unani formulations in the comprehensive management of diabetes as these compounds also exhibited antioxidant and hypolipidemic activity, restored enzymatic functions, repair, and regeneration of pancreatic islets and the alleviation of liver and renal damage as evident by the review. Deficiency of insulin causes disorder of metabolism of carbohydrate, protein and fat, and these drugs are probably used for correction of a defect of liver and stomach as indicated in classical Unani text and improvement of the functioning of liver also improves the metabolism and ultimately can improve the disease condition in DM. Several bitter drugs are used in the Unani formulation for the treatment of DM, dafe Ziabetus (anti-diabetic) activity is found as a direct indication in some of the bitter drug, or it can also be used in accordance to the etiopathogenesis of diabetes and its complications, several of these bitter drugs are termed as Musaffi-i-Dam. Musaffi-i-Dam (Blood Purifiers) drugs make certain action on blood due to which harmful constituents are altered in such constituents, which are then eliminated easily. Besides, this many drugs / formulation are cardio-protective, neuroprotective, and nephroprotective. Unani polyherbal formulations contain several phytoconstituent which can be responsible for other related activity to control diabetic complications.

Etiologic factor implicated in the development and complication of diabetes is the damage induced by free radicals, and hence an anti-diabetic formulation compound with antioxidant properties would be more beneficial, and ingredients of several Unani formulations possess significant antioxidant property. Numerous physicians of the modern system of medicine are prescribing natural compounds containing flavonoids for their antioxidant potential. Furthermore, oxidative stress has a great role in damaging the insulin-producing cells of the pancreas and diabetic complications in DM. ${ }^{[101,102]}$ Probable mechanism and benefit of medicinal plants present in these formulations are from their antioxidant activities. Most of the medicinal plants with anti-diabetic property possess significant antioxidant activity. Vegetables and fruits antioxidant in comparison to synthetic antioxidants can be more effective due to less alternative dispute resolution and are able to decrease the risk of DM. This oxidative stress usually causes or exacerbates chronic hard curable diseases including diabetes. ${ }^{[103]}$

Many drugs in the formulation such as Jamun act by improving the ability of the body's tissues to absorb glucose, thus enhancing the effectiveness of insulin. Gudmar and Gilo which is commonly used in marked Unani formulations can cause regeneration of $\beta$-cell, many drug causes increased in glucose transport and its incorporation into muscle glycogen and increased insulin secretion or stimulation of insulin secretion. Many drugs also act by suppressing carbohydrate absorption from the small intestine and Unani formulations containing these drugs can reduce the postprandial glucose level for better management of blood sugar. Gulnar is indicated in Unani medicine for the treatment of DM since centuries and mentioned by eminent Unani scholars such as Jurjani $^{[16]}$ and Majoosi ${ }^{[104]}$ have now gain renewed interest 
due to Pomegranate flower which has dual peroxisome proliferator-activated receptor (PPAR)- $\alpha /-\gamma$ activator properties (which are a major regulators of lipid and glucose metabolism) and are a natural PPAR $\alpha$ and $\gamma$ agonist. ${ }^{\left[{ }^{[2]}\right]}$ Some drugs in the formulations display extra-pancreatic actions. We can conclude that these formulations are holistic in their approach.

In Unani medicine different formulation is available for treatment / control of diabetes and its complication with a holistic approach and with higher safety margin which is required for the management of this chronic metabolic disorder. These formulations can play an important role in promoting healthy life in diabetics. Constrain related to these formulations is that which this review clearly indicates is that several authentic pharmacopeial preparations are still not marketed and which can be very beneficial if it reaches through as a pharmacopeial preparations. Several works displayed higher dosage for their proper activity in DM, and there is a need for the reconsideration of dosage of this formulation because under-dosing is quite common when marketed formulations are concerned, higher dose limit can be indicated by review of authentic text in this regard. Adjuvant studies on these formulations with contemporary drug or treatment procedure of DM is lacking. These formulations can also be utilized as an adjuvant with the conventional drug due to its diverse and related beneficial pharmacological activity in diabetes and its complications.

\section{CONCLUSION}

The present review reveals that there is the tremendous scope of Unani single drugs and compound formulations in the comprehensive management of diabetes (particularly type-2 diabetes), so it can also be utilized as an adjuvant with the conventional drug due to its diverse and related beneficial pharmacological activity in diabetes and on its complications.

\section{REFERENCES}

1. Joseph B, Jinni D. Insight into hypoglycemic effect of traditional Indian herbs used in the treatment of diabetes. Res J Med Plants 2011;5:352-76.

2. Makheswari MU, Sudarsanam D. Phytomedicine for diabetes mellitus. An Overview. Res Pharm 2011;1:28-37.

3. Wild S, Roglic G, Green A, Sicree R, King H. Global prevalence of diabetes: Estimates for the year 2000 and projections for 2030. Diabetes Care 2004;27:1047-53.

4. Akter S, Rahman MM, Abe SK, Sultana P. Prevalence of diabetes and prediabetes and their risk factors among Bangladeshi adults: A nationwide survey. Bull World Health Organ 2014;92:204-13, 213A.

5. World Health Organization. Global Report on Diabetes. 2016 Available from: apps.who.int/iris/ bitstream/10665/204871/1/9789241565257_eng.pdf. [Last accessed on 2017 Jan 25].

6. Kahkashan Z, Rehman SZ, Tajuddin N, Latif A, Jahan N. Hypoglycemic activity of Berg-e-Arusa and Shoneez. Indian J Tradit Knowl 2009;8:410-2.

7. Alam, Aftab, M. Y. Siddiqui, and M. H. Hakim. "Clinical efficacy of Withania coagulans Dunal and Trigonella foenum-graecum Linn. In Type 2 diabetes mellitus. Indian J Tradit Knowle 2009;8:405-9.

8. Matough FA, Budin SB, Hamid ZA, Alwahaibi N, Mohamed J. The role of oxidative stress and antioxidants in diabetic complications. Sultan Qaboos Univ Med J 2012;12:5-18.

9. Prediabetes and Insulin Resistance. Available from: https://www.niddk.nih.gov/health-information/diabetes/ types/prediabetes-insulin-resistance,modified. [Last accessed on 2009 Aug 21]

10. Quraishi HA, Islam N, Sheeraz M, Iqbal A, Qayyoom R, Bhat $\mathrm{S}$, et al. Unani herbal medicine as an adjuvant therapy in treatment of diabetes mellitus: A review study paripex. Indian J Res 2018;7:30-1.

11. Cade WT. Diabetes-related microvascular and macrovascular diseases in the physical therapy setting. Phys Ther 2008;88:1322-35.

12. Complications of Diabetes, International Diabetes Federation. Available from: http://www.idf.org/ complications-diabetes. [Last accessed on 2016 Dec 21].

13. Gupta R, Bajpai KG, Johri S, Saxena AM. An overview of Indian novel traditional medicinal plants with antidiabetic potentials. Afr J Tradit Complement Altern Med 2007;5:1-7.

14. Kantoori GH. Kmil-us-Sana. (Urdu Translation). New Delhi: Idara Kitabus Shifa; Reprint; 2010. p. 469-70.

15. Khan MA. Aksee-re-Azam. New Delhi: Idara Kitabus Shifa;2011. p. 705-9.

16. Jurjani MI. Zakheera Khawarzam Shahi (Munshi Nawal Kishore, Lucknow. 1878; 540 Urdu Translation) (Urdu Translation Reprint). $6^{\text {th }}$ ed. New Delhi: Idara Kitabus Shifa; 2010. p. 501-2.

17. Zahar AM. Kitabul Taiseer(Urdu). New Delhi: CCRUM, Ministry of Health and Family Welfare, Government of India; 1986. p. 162.

18. Arzani MA. Meeza-Nul-Tib. New Delhi: Idara Kitabus Shifa; 2002. p. 304-5.

19. Kabiruddin M. Alqarabadeen. New Delhi: CCRUM, Ministry of Health and Family Welfare, Government of India; 2006. p. 939-45.

20. Ghani N. Qarabadeen Nazmul Ghani. New Delhi: CCRUM, Ministry of Health and Family Welfare, Government of India; 2010. p. 750-5.

21. Anonymous. Qarabadeen Majeedi. New Delhi: Ajanta Offset and Packaging Ltd.; 1986. p. 270-5.

22. Ministry of Health and Family Welfare National Formulary of Unani Medicine. Part-I. New Delhi: Ministry of Health and Family Welfare, Govt of India; 2006.

23. Kamalinejad M, Larijani B. A systematic review of the 
antioxidant, anti-diabetic, and anti-obesity effects and safety of triphala herbal formulation. J Med Plants Res 2013;7.:831-44.

24. Multani HC, Tajul Hikmat. Lahore: Malik Book Depot; 2008. p. 277.

25. Qurshi MH, Jame-ul-Hikmat. Vol 1, 2. New Delhi: Idara Kitabus-us-Shifa; 2011. p. 869.

26. Asbab S. Tarjuma Kabeer Mukammal. New Delhi: Idara Kitabus-us-Shifa; 2009. p. 34.

27. Hafeez A. Qarabadeen Jadeed. New Delhi: CCRUM; 2005. p. 167.

28. Khan MS. Bayaz-e-Khas Almaruf Ilaj-ul-Amraaz. New Delhi: Aijaz Publishing House; 2004. p. 772-3.

29. Kabeeruddin N. Bayaze Kabeer. Hyderabad: Hikmat Book Depot; 1935. p. 107-9.

30. Jeelani G. Kitabul Murakkabat Almaruf Makhzanul Murakkabat. New Delhi: Aijaz Publishing House; 1995. p. 270.

31. Rahman ZS. Kitab Al Murakkabat. Aligarh: Ibne Sina Acadmy; 2010. p. 131-3.

32. Sharma M, Nagori K, Swarnakar H, Vaishnav S, Nazir M, Khan N, et al. A study on current marketed formulation of Unani medicine used in the treatment of Zayabetus. Int J Allied Med Sci Clin Res 2014;2:51-63.

33. Ahmed D, Sharma M, Mukerjee A, Kant RK, Kumar V. Antidiabetic, anti-hyperlipidemic and hepatoprotective effect of a polyherbal unaniformulation "qurs tabasheer" in STZ-diabetic wistar rats. BMC Complement Altern Med 2013;13:1-45.

34. Abdin MZ, Abrol YP. Traditional System of Medicine. New Delhi: Narosa Publishing House; 2006. p. 114, $123,13,304-7$.

35. Ali H, Anwar M, Ahmad T. Clinical evaluation of gurmar booti and gilo sabz (safoof ziabetus) in the management of diabetes mellitus Type-2. J Res Unani Med Banglore 2012;1:23-8.

36. Mirola A, Kabiraz M, Islam R, Ghani A. Chemical constituents and pharmacological properties of capsule gurmar - A new anti-diabetic formulation of Hamdard laboratories (Waqf) Bangladesh. Stamford J Pharm Sci 2010;3:18-27.

37. Somani R, Shaikh A, Jain D, Shete R. Prokinetic effect of herbomineral unani formulation (dolabi) in diabetic rats. J Res Educ Indian Med 2012;18:1-6.

38. Baig MA, Gawali VB, Patil RR, Naik SR. Protective effect of herbomineral formulation (Dolabi) on early diabetic nephropathy in streptozotocin-induced diabetic rats. J Nat Med 2012;66:500-9.

39. Rahman IU, Idrees M, Rahman KU, Khan MI, Jan NU. Hypoglycemic potential of herbal product dolabi compared with pioglitazone in streptozotocin-induced diabetic rats. Chin J Integr Med 2016. DOI: 10.1007/ s11655-016-2583-1.

40. Kumar SP. Pharmacodynamic evaluation of hypoglycemic effect of damtab in healthy adult male volunteers. Orient Pharm Exp Med 2007;7:205-10.

41. Ahmad S, Siddiqui MA. Study of Diabetic Nephropathy and Evaluation of Unani Formulation in its Management MD Dissertation, Karnataka, Bangalore: Rajiv Gandhi University of Health Sciences; 2011.

42. Qadri M, Rehman ZU, Shireen K. Evaluation of antidiabetic activity of diabrid, a herbal formulation, in Type-II diabetic patients. J Chem Soc Pak 2006;28:281-3.

43. Maaz M. Evaluation of anti-diabetic effects of "qursE-ziabetes": A polyherbal unani preparation in Type 2 diabetes mellitus. Int J Pharm Phytopharm Res 2014;8:3.

44. Anas M, Mohsin M, Siddiqui M, Mannan A. Therapeutic evaluation of a polyherbal formulation in Type 2 diabetes mellitus. Indian J Tradit Knowl 2011;10:711-5.

45. Qutubuddin K, Mohd A. Clinical study on a unani formulation in management of Ziabetus Shakari (Diabetes mellitus Type 2). Int $\mathrm{J}$ Pharm India 2013;2:651-9.

46. Fathima N, Anwar M. Study of Diabetic Peripheral Neuropathy and Therapeutic Evaluation of Unani Formulation in its Management MD Dissertation. Karnataka, Bangalore: Rajiv Gandhi University of Health Sciences; 2011.

47. Koneru A, Satyanarayana S, Mukkanti K, Khan KA. In vitro antioxidant activity of itrifal kishneezi: A unani formulation. Am J Drug Discov Dev 2011;2:121-8.

48. Ribes G, Sauvaire Y, Baccou JC, Valette G, Chenon D, Trimble ER, et al. Effects of fenugreek seeds on endocrine pancreatic secretions in dogs. Ann Nutr Metab 1984;28:37-43.

49. Riyad MA, Abdul-Salam SA, Mohammad SS. Effect of fenugreek and lupine seeds on the development of experimental diabetes in rats. Planta Med 1988;54:286-90.

50. Alarcon-Aguilara FJ, Roman-Ramos R, PerezGutierrez S, Aguilar-Contreras A, Contreras-Weber CC, Flores-Saenz JL, et al. Study of the anti-hyperglycemic effect of plants used as antidiabetics. J Ethnopharmacol 1998;61:101-10.

51. Ravikumar P, Anuradha CV. Effect of fenugreek seeds on blood lipid peroxidation and antioxidants in diabetic rats. Phytother Res 1999;13:197-201.

52. Stark A, Madar Z. The effect of an ethanol extract derived from fenugreek (Trigonella foenum-graecum) on bile acid absorption and cholesterol levels in rats. $\mathrm{Br}$ J Nutr 1993;69:277-87.

53. Modak M, Dixit P, Londhe J, Ghaskadbi S, Devasagayam TP. Indian herbs and herbal drugs used for the treatment of diabetes. J Clin Biochem Nutr 2007;40:163-73.

54. Patel DK, Prasad SK, Kumar R, Hemalatha S. An overview on antidiabetic medicinal plants having insulin mimetic property. Asian Pac J Trop Biomed 2012;2:320-30.

55. Broca C, Gross R, Petit P, Sauvaire Y, Manteghetti M, Tournier M, et al.4-hydroxyisoleucine: Experimental evidence of its insulinotropic and antidiabetic properties. Am J Physiol 1999;277:E617-23. 
56. Haeri MR, Izaddoost M, Ardekani MR, Nobar MR, White KN. The effect of fenugreek 4-hydroxyisoleucine on liver function biomarkers and glucose in diabetic and fructose-fed rats. Phytother Res 2009;23:61-4.

57. Sharma RD. Hypoglycemic effect of gum acacia in healthy human subjects. Nutr Res 1985;5:1437-41.

58. Mostafa S, El-Shenawy A. Biological activities of Eugenia jambolana (Family Myrtaceae). In: Preedy VR, Watson RR, Patel VB. Nuts and Seeds in Health and Disease Prevention. San Diego, CA: Academic Press; 2011. p. 688.

59. Anzar MA. Drugs indicated for the management of ziabetus shakri (diabetes mellitus) in unani medicine - An overview. Int J Pharm India 2013;1:460-74.

60. Achrekar S, Kaklij GS, Pote MS, Kelkar SM. Hypoglycemic activity of Eugenia jambolana and Ficus bengalensis: Mechanism of action. In Vivo 1991;5:143-7.

61. Bhaskar A, Kumar A. Antihyperglycemic, antioxidant and hypolipidemic effect of Punica granatum L flower extract in streptozotocin induced diabetic rats. Asian Pac J Trop Biomed 2012;2:S1764-9.

62. Li Y, Qi Y, Huang TH, Yamahara J, Roufogalis BD. Pomegranate flower: A unique traditional antidiabetic medicine with dual PPAR-alpha/-gamma activator properties. Diabetes Obes Metab 2008;10:10-7.

63. Kam A, Li KM, Razmovski-Naumovski V, Nammi $\mathrm{S}$, Shi J, Chan $\mathrm{K}$, et al. A comparative study on the inhibitory effects of different parts and chemical constituents of pomegranate on $\alpha$-amylase and $\alpha$-glucosidase. Phytother Res 2013;27:1614-20.

64. Roman-Ramos R, Flores-Saenz JL, Alarcon-Aguilar FJ. Anti-hyperglycemic effect of some edible plants. J Ethnopharmacol 1995;48:25-32.

65. Munish G, Chanchal G, Mukherjee PK, Suresh B. Antioxidant potential of Lactuca sativa. Anc Sci Life 2004;24:6.

66. Jelena DM, et al. Antioxidant and Antimicrobial activities of lettuce. $4^{\text {th }}$ International Scientific Symposium Agrosym 2013. Jahorina, Bosnia and Herzegovina. Book of Proceedings. Faculty of Agriculture, University of East Sarajevo; 2013.

67. Ali W, Ahmad HA, Mohammad A, Nasir A. Tukhme kahu (Lactuca sativa Linn): Pharmacological and phytochemical profile and uses in unani medicine. J Pharm Sci Innov 2016;5:1-4.

68. Ross IA. Medicinal Plant of World. $2^{\text {nd }}$ ed., Vol. 1. Totowa New Jersey: Humana Press Inc.; 2007. p. 405-10.

69. Sanja SD, Sheth NR, Patel NK, Patel D, Patel B. Characterization and evaluation of antioxidant activity of P. oleracea. Int J Pharm Pharm Sci 2009;1:74-84.

70. Ali W, Haque HN, Ahmad A. Tukhme khurfa (Portulaca oleraceae Linn.) a plant origin drug of unani medicine: An overview. J Pharm Sci Innov 2015;4:83-6.

71. Kannan VR, Rajasekar GS, Rajesh P, Balasubramanian V, Ramesh N, Solomon EK, et al. Anti-diabetic activity on ethanolic extracts of fruits of Terminalia chebula Retz. alloxan induced diabetic rats. Am J Drug Discov Dev 2012;2:135-42.

72. Murali YK, Anand P, Tandon V, Singh R, Chandra R, Murthy PS, et al. Long-term effects of Terminalia chebula retz. On hyperglycemia and associated hyperlipidemia, tissue glycogen content and in vitro release of insulin in streptozotocin induced diabetic rats. Exp Clin Endocrinol Diabetes 2007;115:641-6.

73. Nalamolu KR, Nammi S. Antidiabetic and renoprotective effects of the chloroform extract of Terminalia chebula retz. Seeds in streptozotocin-induced diabetic rats. BMC Complement Altern Med 2006;6:17.

74. Sabu MC, Kuttan R. Antidiabetic and antioxidant activity of Terminalia belerica. Roxb. Indian J Exp Biol 2009;47:270-5.

75. Petchi RA, Parasuraman S, Vijaya C, Darwhekar DG. Antidiabetic effect of kernel seeds extract of Mangifera indica (Anacardiaceae). Int $\mathrm{J}$ Pharm Bio Sci 2011;2:385-93.

76. Boskabady MH, Shafei MN, Saberi Z, Amini S. Pharmacological effects of Rosa damascena. Iran J Basic Med Sci 2011;14:295-307.

77. Kuroda M, Mimaki Y, Honda S, Tanaka H, Yokota S, Mae T. Phenolics from Glycyrrhiza glabra roots and their PPAR- $\gamma$ ligand-binding activity. Bioorganic Med Chem 2010;18:962-70.

78. Gray AM, Flatt PR. Evaluation of the antidiabetic effects of coriander (Coriandrum sativum). Proc Nutr Soc 1997;56:45A.

79. Gray AM, Flatt PR. Insulin releasing and insulin-like activity of the traditional antidiabetic plant Coriandrum sativum (coriander). Br J Nutr 1999;81:203-20.

80. Srinivasan K. Plant foods in the management of diabetes mellitus: Spices as beneficial antidiabetic food adjuncts. Int J Food Sci Nutr 2005;56:399-414.

81. Akhani SP, Vishwakarma SL, Goyal RK. Anti-diabetic activity of Zingiber officinale in streptozotocin-induced Type I diabetic rats. J Pharm Pharm 2004;56:101-5.

82. Rani MP, Krishna MS, Padmakumari KP, Raghu KG, Sundaresan A. Zingiber officinale extract exhibits antidiabetic potential via modulating glucose uptake, protein glycation and inhibiting adipocyte differentiation: An in vitro study. J Sci Food Agric 2012;92:1948-55.

83. Sachan NK, Kumar Y, Pushkar S, Thakur RN, Gangwar SS, Kalaichelvan VK. Antidiabetic potential of alcoholic and aqueous extracts of Ficus racemosa Linn. Bark in normal and alloxan induced diabetic rats. Int J Pharm Sci Drug Res 2009;1:24-7.

84. Ahmed F, Urooj A. Glucose-lowering, hepatoprotective and hypolipidemic activities of stem bark of Ficus racemosa in streptozotocin-induced diabetic rats. J Young Pharm 2009;1:160.

85. Amin M, Bhakta S, Das SK. Anti-diabetic potential of Ficus racemosa: Current state and prospect especially in the developing countries. J Biosci Agric Res 2015;5:65-72.

86. Yeh GY, Eisenberg DM, Kaptchuk TJ, Phillips RS. 
Systematic review of herbs and dietary supplements for glycemic control in diabetes. Diabetes Care 2003;26:1277-94.

87. Wadkar KA, Magdum CS, Patil SS, Naikwade NS. Antidiabetic potential and Indian medicinal plants. J Herbal Med Toxicol 2008;2:45-50.

88. Rchid H, Chevassus H, Nmila R, Guiral C, Petit P, Chokaïri $\mathrm{M}$, et al. Nigella sativa seed extracts enhance glucose-induced insulin release from rat-isolated Langerhans islets. Fundam Clin Pharm 2004;18:525-9.

89. Le PM, Benhaddou-Andaloussi A, Elimadi A, Settaf A, Cherrah Y, Haddad PS, et al. The petroleum ether extract of Nigella sativa exerts lipid-lowering and insulin-sensitizing actions in the rat. J Ethnopharmacol 2004;94:251-9.

90. Swamy SM, Tan BK. Cytotoxic and immune-modulatory effects of ethanolic extract of Nigella sativa L. seeds. J Ethnopharm 2000;70:1-7.

91. Benhaddou-Andaloussi A, Martineau L, Vuong T, Meddah B, Madiraju P, Settaf A, et al. The in vivo antidiabetic activity of Nigella sativa is mediated through activation of the AMPK pathway and increased muscle glut 4 content. Evid Based Complement Alternat Med 2011;2011:538671.

92. Labhal A, Settaf A, Zalagh F, Cherrah Y, Hassar M, Slaoui A. Antidiabetic properties of Nigella sativa seeds in the obese and diabetic shawi merione, hypoglycemic effects of a suspension of Nigella sativa in obese and diabetics. Med Esperance 1999;6:72-4.

93. El-Dakhakhny M, Mady N, Lembert N, Ammon HP. The hypoglycemic effect of Nigella sativa oil is mediated by extrapancreatic actions. Planta Med 2002;68:465-6.

94. Ashraf SS, Rao MV, Kaneez FS, Qadri S, Al-Marzouqi AH, Chandranath IS, et al. Nigella sativa extract as a potent antioxidant for petrochemical-induced oxidative stress. J Chromatogr Sci 2011;49:321-6.
95. Rajalakshmi M, Eliza J, Priya CE, Nirmala A, Daisy P. Anti-diabetic properties of Tinospora cordifolia stem extracts on streptozotocin-induced diabetic rats. Afr J Pharm Pharm 2009;3:171-80.

96. Shukla R, Sharma SB, Puri D, Prabhu KM, Murthy PS. Medicinal plants for treatment of diabetes mellitus. Indian J Clin Biochem 2000;15:169-77.

97. Roy P, Abdulsalam FI, Pandey DK, Bhattacharjee A, Eruvaram NR, Malik T, et al. Evaluation of antioxidant, antibacterial, and antidiabetic potential of two traditional medicinal plants of India: Swertia cordata and Swertia chirayita. Pharm Res 2015;7:S57-62.

98. Haytham MD, Abas MM. Mohammad MA, Jaffar MM. Antidiabetic effect of Artemisia absinthium extracts on alloxan-induced diabetic rats. Comp Clin Pathol 2014;23:1733-42.

99. Al-Waili NS. Treatment of diabetes mellitus by Artemisia herba-alba extract: Preliminary study. Clin Exp Pharmacol Physiol 1986;13:569-73.

100. GOI Ministry of Health and Family Welfare. The Unani Pharmacopoeia of India. Part 1, Vol. 2. New Delhi: GOI Ministry of Health and Family Welfare, Department of AYUSH; 2007.

101. Havsteen BH. The biochemistry and medical significance of the flavonoids. Pharm Ther 2002;96:67-202.

102. Tiwari AK, Prashad P, Thelma BK, Kumar KM, Ammini AC, Gupta A, et al. Oxidative stress pathway genes and chronic renal insufficiency in Asian Indians with Type 2 diabetes. J Diabetes Complications 2009;23:102-11.

103. Nasri H, Shirzad H, Baradaran A, Rafieian-kopaei M. Antioxidant plants and diabetes mellitus. J Res Med Sci 2015;20:491-502.

104. Majoosi AI. Kamilussanah. Lucknow: Munshi Nawal Kishore; 1889. p. 145.

Source of Support: Nill. Conflict of Interest: None declared. 